\title{
Personality Traits and Ethical Belief as Factors Influencing Fraud Intent Behaviour among Bank Employees in Ibadan, Nigeria
}

\author{
Ajibola Abdulrahamon Ishola a 1 iD , Akeem Adekunle Kenku ${ }^{\text {b }}$ iD , Olufunmilayo Adedayo ${ }^{c}$ \\ ${ }^{a}$ Department of Psychology, University of Ibadan, Nigeria \\ ${ }^{b}$ Nasarawa State University, Keffi, Nigeria \\ ${ }^{c}$ Adeyemi College of Education, Ondo, Nigeria
}

\section{APA Citation}

Ishola, A. A., Kenku, A. A., Adedayo, A. (2021). Personality traits and ethical belief as factors influencing fraud intent behaviour among bank employees in Ibadan, Nigeria. TIJAB (The International Journal of Applied Business), 5(1), 94-109.

Submission Date: $14 / 04 / 2021$

Acceptance Date: $27 / 04 / 2021$

\begin{abstract}
Fraud is an ever-growing problem for financial institutions in Nigeria, with criminals using a wide variety of methods. Unfortunately, employees were fingered in most of these fraudulent activities. Previous studies focused on contextual and organizational antecedents of motivating engagement in fraudulent practices and less on employees' dispositional factors. This study examined the role of personality traits and ethical beliefs on fraudulent behaviour among bank employees. The study was a cross-sectional study. Three hundred and fifty-three (353) employees in the middle to junior level management cadre were selected through stratified sampling technique from banking organisations operating in the Ibadan metropolis. The respondents responded to a self-report questionnaire measuring fraudulent behaviour intention and red flags; personality traits and Ethical position questionnaire. Two hypotheses were tested using multiple regression, Pearson correlation analysis and ANOVA at $\mathrm{p} \leq 0.05$. Results demonstrated that conscientiousness personality trait was the only predictor of fraud intent behaviour among the personality variables. Employees with Absolutist ethical principles reported lower fraud intent behaviour than those with subjectivist ethical philosophy. The study concludes that personality traits and ethical beliefs were powerful motivators for fraud behavior. Thus, fraud and HR experts were enjoined to utilize psychological profiles in fraud investigations and selection of employees.
\end{abstract}

Keywords: bank fraud, personality traits, conscientiousness trait, ethical belief, absolutist ethical belief, bank employees

This is an open access article under the CC BY-NC-SA license.



\section{Introduction}

The economy, and the business world depend on the trustworthiness and integrity of banks and their employees. The effectiveness of the corporate governance of banks relies on the ethics, trust and

\footnotetext{
${ }^{1}$ Corresponding author.

E-mail address: ajibola_ishola@yahoo.co.uk
} 
independence which constrain the behaviour of banking organisation actors. When ethical principles are lacking in the banking system, criminal acts may pervade the system. The most pertinent of these problems is the problem of fraudulent practices and unethical acts going on in the sector. Fraud in the broadest term means obtaining something valuable or avoiding an obligation through deception (Duffield \& Grabosky, 2001). Existing research showed that fraudulent acts in the Nigerian banking system are perpetrated by both employees and non-employees. These wrongdoings are an aftermath of collusion between the bank representatives and fraudsters. Staffers that were engaged in fraud cases most times were those in the nitty-gritty of banking operations, for example, accountants, bank supervisors, tellers, clerks and managers (Balogun, Selemogwe, \& Akinfala, 2013). Owolabi (2010) identified that bank employees were discovered to be involved in more than $70 \%$ of fraudulent behaviour in the banking sector, and Idolor (2010) noted that bank staff did not draw the boundary between unofficial borrowing and foreign exchange malpractices as forms of bank fraud.

In Nigeria, news of fraud or attempted fraud has become prominent (Abiola \& Adedokun, 2018; Balogun et. al., 2013) and tends to undermine the bank's credibility by reducing public trust in the banking sector. In the Nigerian banking sector typical fraudulent activities include issuing or overdrafting unlawful loans, presenting checks forgery, publishing fake credits, fraudulent transfers and withdrawals, removing cash or cheques and suppression of cheques (Balogun et al., 2013). These bank failures prompted huge financial misfortune to investors and loss of integrity in the banking system. In 2018, the Central Bank of Nigeria detailed (CBN) uncovered that commercial banks in the nation lost an aggregate of N12.06 billion to fraud in the first quarter of 2018. As indicated by the report, there were 20,768 documented instances of fraud and falsification (endeavored and effective), esteemed at N19.77 billion in the audit time frame, and these contrasted 16,762 cases, N5.52 billion and US\$ 0.12 million reported in 2017. (Udeh \& Ugwu, 2018).

According to Duffield and Grabosky (2001) fraud has a three-factor motivation; a good number of motivated offenders, the availability of attractive targets, and the unavailability of dependable guardians. The motivation to commit a fraudulent behaviour is a combination of an individual's personality, moral ethics and the situation or context. Personality has to do with individual's unique and relatively stable pattern of behaviours thoughts and emotions. Certain personality traits have been identified as factors that could predispose bank employees to fraudulent activities.

The big-five factor dimension of personality and a more theoretical breakdown of the factor traits of major personality measures revealed that dimensions of the big five personality dimension have a key role to play in the emergence and act of antisocial and criminal behaviour. One of its dimensions, Conscientiousness is a framework that refers to the extent to which goal-directed persons are organised, regulated and motivated. Persons with high conscientiousness tend to be organised, confident, hardworking, self-managing, scrupulous while persevering, and people with low conscience tend to be fainthearted, unattended, lax, impulsive and reckless. (Adebayo \& Nwabuoku, 2008). The second dimension, agreeableness describes a trait which range from good nature gentle cooperative and helpful on one end to being irritable, ruthless, suspicious, uncooperative and head strong on the other end (Sinha, 2004). This trait has been associated with work place deviance and low job performance (Sinha, 2004). The third personality traits, openness to experience trait dimension, which range from being imaginative, sensitive, intellectual, polished at one end to being down to health, insensitive, narrow, crude and simple at the other end, was also alleged to enhance antisocial and counterproductive behaviour because of high novelty or enhanced ability to circumvent the internal control system in the work place to suite personal purpose since openness to experience have been associated with high cognitive ability and creativity (Sinha, 2004). These studies proposed that these personality traits in combination or individually may predispose employees to fraud behaviour because they have been implicated in employees' unethical practices. 
Scholars and managers have also considered a number of other possible explanations for fraud; such as competitive economic environments, the organizational culture, and personal morals. Among these ethical belief factors stand out as most significant (Bezuidenhoud, 2014; Burnett, 2017; Manurung, Suhartadi, \& Saefudin, 2015; Zulaikha \& Hadiprajitno, 2016; Weber, Kurke, \& Pentico, 2003). What regulates individuals' choices of appropriate behaviours, beliefs and thought towards others is what is regarded as ethics. Ethics is defined as a set of moral principle or values that governs the conduct of an individual (Trevino \& Nelson, 2007). In all organisations, individuals have been found to differ in ethical judgment of what is right or wrong because of individual differences in personal ethical ideology or principle (Monga, 2005). Schlenker and Forsyth (1977), divided these personal ethical ideology or "moral" judgment into two evaluative dimensions; relativism and idealism. Idealism refers to the degree to which an individual considers the welfare of others in evaluating the outcome of alternative cause of action. Boyle (2000) clarified that those with high idealism accept the most appealing option is the one that limits harm to other people and those with low ideals place priority on the overall outcome, regardless of whether or not people are hurt. Relativism describes putting emphasis on situational conditions encompassing a moral predicament versus a general standard of behaviour. Those high on relativism see each circumstance as an uncommon situation that is utilized as essential reason for shaping moral judgment. Those low on relativism apply a standard code of behaviour in all circumstances.

The interaction of these ethical beliefs produced four orders of people's moral belief systems. The first; a situationist who demonstrates a high level of idealism and relativism dismisses the idea of a general moral code and accepts that moral choices are constantly based on the circumstance (Gurbuz \& Eris, 2015). Second, a subjectivist likewise depicts a high level of relativism but a low level of idealism. To a subjectivist, there is absence of external moral good gauges, what is viewed as right is dictated by one's very own qualities and viewpoints (Gurbuz \& Eris, 2015). Third, the absolutist shows a high level of idealism and a low level of relativism. This mirrors the idea that ethical decisions depend on personal value and points of view (Gurbuz \& Eris, 2015) but the 'rightness' of an action relies upon the outcomes of the activity (Gurbuz \& Eris, 2015). The fourth and last grouping of moral belief system is the exceptionist, which scores a low degree on both idealism and relativism (Gurbuz \& Eris, 2015). The exceptionist considers an all-inclusive general moral code as imperative, be that as it may, executing such principles ought to be made by considering the circumstance or conditions surrounding the context and the outcomes (Ward, 2013). Following Duffield and Grabosky (2001) fraud model we test the model that Motivation for fraud or intent is influenced by dispositional factor; personality and ethical belief philosophy. This study thus examined the influence of personality traits ie conscientiousness, Agreeableness, Openness to experience and Ethical belief on fraud intent behaviour of bank employees. The specific objectives of this study include:

1. Explore the relationship between the personality traits, ethical beliefs and some characteristics of bank employees and fraudulent intent behaviour.

2. Test the hypothesis whether bank employees' personality traits of conscientiousness, Agreeableness and Openness to experience would jointly and singly predict fraudulent intent behaviour.

3. Investigate the influence of ethical belief types on fraudulent intent behaviour among bank employees.

\section{Literature Review}

The theory utilised in the study was introduced by Cohen and Felson (1979) called the "Routine activities theory". This theory takes into consideration the criminal event, the offender`s motivation, and situation factors. By rational choice is meant that offenders process information and evaluate alternatives before the decision is taken. The motivation to commit a fraudulent behaviour is a combination of an individual's personality, moral ethics and the situation or context (Duffield \& Grabosky, 2001). This 
study test the assumptions that personality traits and ethical belief will motivate or influence fraud behaviour among bank employees.

\subsection{Personality traits and fraudulent behaviour}

The theory utilised in the study was introduced by Cohen and Felson (1979) called the "Routine activities theory". This theory takes into consideration the criminal event, the offender's motivation, and situation factors. By rational choice is meant that offenders process information and evaluate alternatives before the decision is taken. The motivation to commit a fraudulent behaviour is a combination of an individual's personality, moral ethics and the situation or context (Duffield \& Grabosky, 2001). This study test the assumptions that personality traits and ethical belief will motivate or influence fraud behaviour among bank employees.

Personality has to do with individual's unique and relatively stable pattern of behaviours thoughts and emotions (Turner, 2014). The personality of an individual is a relatively stable factor which hold most of the behaviour constant in many situations and many a time the explanation given is that the greed traits in individuals cause fraudulent behaviour which is rather over simplistic and naïve (Duffield \& Grabosky, 2001). Certain personality traits have been identified as factors that could predispose bank employees to fraudulent activities. Research on the influence of personality on fraudulent behaviour have adopted multi-dimensional approaches to it studies and causality.

Murphy (2011) mentioned that fraud related behaviour studies involves diverse psychological factors peculiar to different fraudulent practices, hence, some dispositional traits are unique to some fraudulent behaviours. In some studies; Buyl, Boone, and Wade, (2017) found that entrepreneur fraud, risky managerial behaviour, and theft in the work place were associated with narcissism. A study also linked conscientiousness trait to job dysfunctional and antisocial behaviour (Chirumbolo, 2017). Camps, Stouten, and Euwema, (2016) reported that work place deviance was more likely to occur when perception of work place is negative, and emotional stability (Neuroticism), conscientiousness and agreeableness are low. Brink, Cereola and Menk (2015) found behavioral features correlated with desire to whistle blow unethical practices. The main predictors of whistleblowing purposes include conscientiousness and extraversion. These demonstrates that personality characteristics are important fraud potentiates.

H1: Bank employees' personality traits of conscientiousness, Agreeableness and Openness to experience will jointly and singly influence fraud intent behaviour of bank employees.

\subsection{Ethical beliefs and fraudulent behaviour}

The application of the right "ethics" impacts the organization at several levels; individuals seeking employment with a trustworthy firm, the firms seeking value driven, qualified employees, the client seeking a reputable company with conscientious employees and an organization trying to build a name for itself would have all reached their goals and standard for conduct. However, in a situation where there is dearth of sound ethics, organisations report frequent cases of dysfunctional behaviour and unethical practices (Baskaran, Yang, Yi, \& Mahadi, 2018) common with developing countries like Nigeria (Ayuba \& Aliyu, 2018). Several studies have demonstrated that personal ethical orientation plays significant role in ethical decision making and subsequent unethical behaviours.

A study found that employees that are low in relativism and high in idealism tend to be stricter with company rules (Poór, Abdulkerim, Ahmet \& Kollár, 2018). Olayiwola, (2016) found that managers in organisations with strong ethical climate in some major Nigeria companies have high job commitment and job satisfaction and are less likely to report wrong doing and fraudulent behaviour in their firms. Brink et al. (2015) also demonstrated that ethical position significantly influenced whistle blowing 
decision. Brink et al. (2015) suggest that persons with an idealistic position (i.e. persons assuming that ethical action guarantees good results) have demonstrated a positive and important connection to the intention of whistleblowing. Thus, we proposed that ethical position is a fraud intention or red flag potentiates.

H2: Ethical belief type will significantly influence employees' fraud intent behaviour.

\section{Method}

The study was planned in a cross-sectional survey. Personality traits and ethical position were independent variables. Fraud intent behaviour and potentiates is the dependent variable in the analysis.

\subsection{Sample / Participants}

Describe the sample or participants who participated in your study and the setting when relevant. In most studies, your participants are likely to be people, but a sample can comprise of a group of cases or items. You should present information related to the sample, such as how the sample was selected, the size of the sample, and relevant demographic characteristics about the sample. You, as the researcherauthor, have to decide which demographic characteristics are relevant to your study. For example, GPA, age, or IQ scores of the study's participants may be considered important demographic characteristics in one study, but not in another. Understandably, the exact information about the sample in your study (e.g., the mean age or the number of males and females in each group) should provide a general description of the study's participants.

\subsection{Instrument(s)}

The Instrument used was a self-report questionnaire which captures biography data for example age, sex, level of education, years of experience and job status. Personality traits of Conscientiousness, Openness to experience and Agreeableness were measured in the study using items drawn from the IPIP personality inventory pool developed by Goldberg (1999). The conscientiousness sub scale items (e.g., "I am always prepared" "I sometimes shirk my duties") ( $\alpha=0.84)$, Openness to experience items e.g., "I am not interested in abstract ideas or philosophies" "I enjoy going movies, theatre and museum") $(\alpha=$ 0.74) and Agreeableness (e.g., "I get back at those who offend" "I believe that others have good intentions") ( $\alpha=0.76)$ had meritorious reliabilities from the source. Each item was scored on a five points scale, ranging from 1 (Strongly agree) to 5 (strongly disagree).

Ethical belief of the bank employees was captured with the 20-item Ethical Position Questionnaire by Forsyth $(1980,1992)$ which consist of two scales of idealism (10 items) and relativism (10 items). The response format ranged from completely disagree (1) to completely agree (5). The scale reported the alphas of 0.86 for idealism and 0.82 for relativism. A median split was performed on the relativism sub-scale to set high versus low relativism; similarly, a middle split was performed on the idealism subscale to set high or low idealism. This made a two (high idealism x low idealism) by two (high relativism $\mathrm{x}$ low relativism) arrangement. These 2 dimensions was used to characterize individuals into four moral sorts: situationists (high relativism, high idealism); absolutists (low relativism, high idealism); subjectivists (high relativism, low optimism); and exceptionists (low relativism, high idealism).

Bank fraud intent behaviour, red flags and potentiates was captured using the 12-item Fraud intent behaviour scale adapted from Alarape (2004) (e.g., "take advantage of weak internal controls to make something for myself" "giving a loan without collateral and receiving a percentage in return") $(\alpha=0.71)$. Response on each item was scored likert format ranging from strongly disagree (1) to strongly agree (5). 


\subsection{Data collection procedures}

The study was a correlational study using the cross-sectional survey strategy. 12 banks were randomly selected from the list of existing banks in the metropolis. The researchers sought the necessary approval from the HR units of each of the banking organisations through formal request which was granted. Prior to questionnaires distribution/administration, consultations were held with the head of human resources unit of each bank to describe the study and motive of the research. The researchers obtain the list of employees and using table of random numbers selected one hundred and fifty employees for the study. The participants were informed about their right to participate or decline to participate in the study. The participants who agreed to the informed consent were then asked to rate the items on the instrument that best describes their opinions on each the questionnaire.

Research participants were guaranteed absolute confidentiality of the information given. Ethical approval for the study was obtained from the Department of Psychology Ethical Review Committee (PSY-20040224). The investigators gave respondents complete information about the study and were given the opportunity whether to partake or not in the study. The investigators also obtained the assent of the respondents previously before administering the questionnaire to them. The Declaration of Helsinki and its revision (World Medical Association, 2001) informed the ethical direction of the investigation.

A total of 450 copies of questionnaires were distributed to potential respondents at their various places of work. The researcher later went back to collect the questionnaires for analysis. Out of the 450 questionnaires distributed, the researchers were able to retrieve 353 which was analysed in the study.

\subsection{Data analysis}

In analysing the collected data, the researcher utilizes the descriptive statistics of simple frequency and percentage to describe the respondent's characteristics. The hypotheses were tested using One-way ANOVA, Pearson correlation analysis and multiple regression analysis at 0.05 level of significance

\section{Results}

Table 1: Socio-demographic characteristics

\begin{tabular}{|c|c|c|c|c|c|c|}
\hline & Variables & & Minimum & Maximum & $M$ & $S D$ \\
\hline 1. & Age & & 20 & 56 & 36.13 & 4.23 \\
\hline 2. & $\begin{array}{l}\text { Years of } \\
\text { Experience }\end{array}$ & & 2 & 23 & 5.41 & 4.72 \\
\hline 3. & $\begin{array}{l}\text { Years in present } \\
\text { org. }\end{array}$ & & 2 & 23 & 4.83 & 4.12 \\
\hline & & Category & $\mathrm{n}$ & $\%$ & & \\
\hline 4. & Sex & $\begin{array}{l}\text { Male } \\
\text { Female }\end{array}$ & $\begin{array}{l}224 \\
125\end{array}$ & $\begin{array}{l}63.4 \\
35.5\end{array}$ & & \\
\hline 5. & Marital status & $\begin{array}{l}\text { Married } \\
\text { Singles } \\
\text { Widowed }\end{array}$ & $\begin{array}{c}156 \\
193 \\
4\end{array}$ & $\begin{array}{c}44.1 \\
54.8 \\
1.1\end{array}$ & & \\
\hline 6. & $\begin{array}{l}\text { Religious } \\
\text { affiliation }\end{array}$ & $\begin{array}{l}\text { Christianity } \\
\text { Islam }\end{array}$ & $\begin{array}{c}285 \\
61\end{array}$ & $\begin{array}{l}80.6 \\
17.2\end{array}$ & & \\
\hline 7. & $\begin{array}{l}\text { Educational } \\
\text { Qualification }\end{array}$ & $\begin{array}{l}\text { BSc. /HND (Banking \& } \\
\text { Accounting) }\end{array}$ & 191 & 54 & & \\
\hline & & OND & 87 & 24.6 & & \\
\hline & & ICAN/ANAN & 47 & 13.4 & & \\
\hline & & $\begin{array}{l}\text { BSc. /HND (Non-related } \\
\text { to Banking/Accounting) }\end{array}$ & 30 & 8.4 & & \\
\hline
\end{tabular}


8. Job position

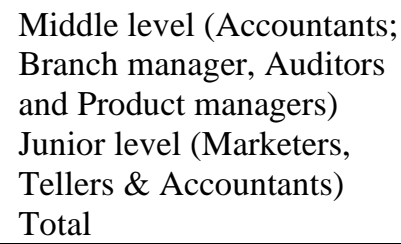

213

60.22

140

353
39.78

100

Three hundred and fifty-three (353) participants were drawn from commercial banks operating within the Ibadan metropolis, Oyo State, Nigeria, through multi-stage sampling technique. Their age ranged from 20 to 56 years with a mean age- $36.13(\mathrm{SD}=4.23)$ years. The larger percentage $(63.4 \%)$ were males while $35.5 \%$ were females. The marital status reveals that $44.1 \%$ were married while $54.8 \%$ were singles and $1.1 \%$ were widowed. Regarding religious affiliation, $17.2 \%$ were Muslims and $80.6 \%$ were Christians. More than half (54\%) have higher educational qualification (Bachelor degree and Higher national Diploma related to Banking \& Finance and Accounting) while 37.6\% have Ordinary National Diploma and Professional qualification. Regarding job status, $60.22 \%$ of the respondents were in the junior staff category (Marketers, Tellers \& Accountants) while $39.78 \%$ were of the middle level management category (Accountants; Branch manager, Auditors and Product managers).

Table 2. Descriptive statistics and reliabilities of the Psychological variables

\begin{tabular}{llccccc}
\hline & & $\alpha$ & Minimum & Maximum & $M$ & $S D$ \\
\hline Personality traits & Agreeableness & 0.76 & 4 & 20 & 13.8 & 5.9 \\
& Conscientiousness & 0.79 & 4 & 20 & 13.7 & 5.8 \\
& Openness to experience & 0.82 & 4 & 20 & 11.5 & 3.8 \\
Ethical beliefs & Idealism & 0.82 & 10 & 50 & 35.6 & 11.8 \\
& Relativism & 0.72 & 10 & 50 & 36.3 & 14.4 \\
Fraud intent behavior & & 0.81 & 12 & 60 & 36.9 & 12.2 \\
\hline
\end{tabular}

Conscientiousness, Openness to experience and Agreeableness demonstrated reliability for present study were $0.76,0.79$ and 0.82 alphas respectively. 0.81 Alpha was recorded in the present study with split-half reliability of 0.77 spearman brown co-efficient. For the ethical beliefs dimensions the reliabilities were 0.82 alpha for idealism and 0.72 alpha for relativism. The reliability for fraud intent scale was 0.81 alpha. Cronbach alpha above 0.7 has been regarded as acceptable level of meritorious reliability (Nunally, 1979).

The relationship between the personality traits, ethical beliefs and demographic characteristics of bank employees and fraudulent intent behaviour was examined, using Pearson $r$ correlation statistical analysis the result is presented in Table 1:

Table 3. Mean, standard deviation, and correlations

\begin{tabular}{|c|c|c|c|c|c|c|c|c|c|c|c|}
\hline Variables & $\bar{x}$ & $S D$ & 1 & 2 & 3 & 4 & 5 & 6 & 7 & 8 & 9 \\
\hline 1. Years of Experience & 5.4 & 4.7 & - & & & & & & & & \\
\hline 2. Years in present org. & 4.8 & 4.1 & $.453^{* *}$ & - & & & & & & & \\
\hline 3. Financial strain & 25.6 & 3.1 & $.264^{* *}$ & $.341^{* *}$ & - & & & & & & \\
\hline 4. Openness & 11.5 & 3.8 & -.039 & -.058 & .032 & - & & & & & \\
\hline 5. Conscientiousness & 13.7 & 5.8 & -.038 & $.125^{*}$ & .038 & $.422^{* *}$ & - & & & & \\
\hline
\end{tabular}




\begin{tabular}{|c|c|c|c|c|c|c|c|c|c|c|c|}
\hline 6. Agreeableness & 13.8 & 5.9 & .078 & $.56^{* *}$ & $.123^{*}$ & $.410^{* *}$ & $.680^{* *}$ & - & & & \\
\hline 7. relativism & 35.6 & 11.8 & .044 & $-.107^{*}$ & -.007 & -.105 & -.036 & .063 & - & & \\
\hline 8. Idealism & 36.3 & 14.4 & .66 & .068 & $.254^{* *}$ & -.040 & .074 & $.206^{*}$ & $.483^{* *}$ & - & \\
\hline 9. Fraud intent behaviour & 36.9 & 12.2 & $-.211^{* *}$ & $-.238^{* *}$ & -.090 & -.094 & $--.392^{* *}$ & $-.29^{* *}$ & $.24^{* *}$ & $-.21^{* *}$ & - \\
\hline
\end{tabular}

The result on the pattern of relationship showed that conscientiousness $(r=-.39, p<0.01)$ and agreeableness $(r=-.29, p<0.01)$ personality traits were significant correlates of fraud intent behaviour. The result demonstrates that fraud intent behaviour decreases with increasing scores on conscientiousness and agreeableness traits. However, the relationship between openness to experience personality trait and fraud intent behaviour was not significant. Meaning that employees who are conscientious and get along with others easily were less prone to fraudulent practices.

Relativism $(r=.24, p<0.01)$ ethical belief was shown to be significant positive significant correlate of fraud intent behaviour. Increasing scores on relativism was associated with increasing fraud intent scores. There was significant inverse relationship between fraud intent and idealism $(r=-.21, p<0.01)$. Increasing idealism ethical belief scores was associated with low or decreasing fraud intent scores. There was significant inverse relationship among years of experience in the field of banking and accounting $(\mathrm{r}$ $=-.21, \mathrm{p}<.01)$, years in present organisation $(\mathrm{r}=-.24, \mathrm{p}<.01)$ and fraud intent behaviour. Increasing years of experience and years spent in the organisation were associated with decreasing fraud behaviour.

H1: Bank employees' personality traits of conscientiousness, Agreeableness and Openness to experience will jointly and singly influence fraud intent behaviour of bank employees.

This hypothesis was tested using multiple regression and the result presented in Table 2.

Table 3: Regression analysis of the influence of conscientiousness, Agreeableness and openness to experience on fraud intent behaviour.

\begin{tabular}{lccccccc}
\hline Variables & $\beta$ & $\mathrm{t}$-value & $\mathrm{P}$ & $R$ & $R^{2}$ & $F$ & $P$ \\
\hline Conscientiousness & -.40 & -4.67 & .000 & & & & \\
Openness Experience & .089 & .827 & .187 & & & & \\
Agreeableness & -.049 & -.364 & .195 & & & & \\
\hline
\end{tabular}

Dependent variable: Fraud intent behaviour

The result from Table 2 showed that summary of the multiple regression analysis. The result revealed that jointly the three personality traits predicted fraud intent behaviour $(\mathrm{F}(3,350) 16.52, \mathrm{p}<.01)$. The three-personality trait were collectively responsible for $16 \%(\mathrm{R} 2=0.16)$ of variance observed in fraud intent behaviour. Only conscientiousness personality traits independently and significantly predict fraud intent behaviour $(\square=-.40, \mathrm{t}=-4.67, \mathrm{p}<.01)$. However, the independent contributions of Agreeableness and openness to fraud intent behaviour were not significant. The hypothesis is supported.

H2: Ethical belief type will significantly influence employees' fraud intent behaviour.

Hypothesis two stated that Ethical belief type will significantly influence employees' fraud intent behaviour. To analyse the influence of four ethical belief types (situationists; absolutists; subjectivists 
and exceptionists) on fraud intent behaviour, a one-way ANOVA test and Tukey post hoc test was used to identify the particular group differences in fraud intent behaviour. First the relativism and idealism scores in to four dimensions based on median split (relativism $=25$; Idealism $=25$ ). Based on median split classification, 158 were classified as having high idealism and 199 low on idealism. Also, 199 were classify as having high relativism and 158 were low on relativism. Using the cross tabulation resulted in to four beliefs types; situationists (86)(high relativism, high idealism); absolutists (68)(low relativism, high idealism); subjectivists (74)(high relativism, low idealism); and exceptionists (125) (low relativism, low idealism). Thus, the hypothesis Ethical belief type will significantly influence fraudulent intent hypothesis was tested with one-way ANOVA and the resulted is presented in Table 3 and Tukey post Hoc test of the mean comparisons and the result is presented in Table 4.

Table 3: One-way ANOVA showing the influence of ethical beliefs on fraud intent behaviour.

\begin{tabular}{llllll}
\hline Source & Sum of squares & $\mathrm{df}$ & Mean square & $\mathrm{F}$ & $\mathrm{P}$ \\
\hline Between Groups & 1288.105 & 3 & 429.368 & 3.078 & .037 \\
Within groups & 11998.295 & 349 & 3.078 & & \\
Total & 13286.4 & 352 & & & \\
& & & & & \\
\hline
\end{tabular}

The result of the F-test in Table 3 showed that there is was significant influence of ethical belief type on fraud intent behaviour. $\mathrm{F}(3,86)=3.08, \mathrm{p} .<0.05$. To identify the particular group differences in fraud intent behaviour, the Tukey post hoc test is presented in Table 4:

Table 4: Tukey post hoc test showing group difference in fraud intent behaviour based on type of ethical belief

\begin{tabular}{lcllllll}
\hline Ethical status & $\mathrm{N}$ & Mean & S.D & 1 & 2 & 3 & 4 \\
\hline Exceptionist & 125 & 41.84 & 12.06 & - & 5.8 & $12.00^{*}$ & 5.71 \\
Subjectivist & 74 & 36.06 & 13.26 & & - & 6.29 & 4.13 \\
Absolutist & 68 & 19.84 & 10.62 & & & - & 6.21 \\
Situationist & 86 & 29.13 & 11.35 & & & & - \\
***al & 353 & 36.8 & 12.21 & & & & \\
Totan difference significant at 0.05 level & & & & &
\end{tabular}

The result of the post hoc Tukey test (in Table 4) revealed that employees with exceptionist ethical status $\left(\mathrm{x}^{-}=41.84\right.$, S.D $\left.=12.06\right)$ reported higher scores on bank fraud intent behaviour than Absolutist $\left(\mathrm{x}^{-}=19.84, \mathrm{~S} . \mathrm{D}=10.62\right)$, (Tukey $\left.=12.00, \mathrm{p}<.05\right)$ while there was no significant differences between the exceptionist, absolutist and situationist ethical positions on fraud intent behaviour of bank employees. The hypothesis was also supported.

\section{Discussion}

\subsection{Discussion}

This study examined the influence of personality traits, ethical orientation, and demographic characteristics on fraudulent behaviour. The results confirmed that conscientiousness and agreeableness traits correlated significantly with fraud intent behaviour. Declining scores on agreeableness and conscientiousness was associated with higher fraud intent. People with low conscience and does not get 
along with other were more prone to engaging in fraud related activities. The results agree with Van Staden (2018) who found that conscientiousness employees are less involved in counterproductive work behaviour. Henle and Gross (2013) found significant associations among low level agreeableness, low level conscientiousness personality traits and workplace deviance. Henle and Gross (2013) also reported a negligible role of openness to experience personality trait in workplace deviance. In the same vein, Sinha, (2004) reported that agreeableness reduces chances of counterproductive work behaviour in ethically work organisations.

Significant relationship was also found between ethical beliefs and fraud intent behaviour. This is consistent with studies which have shown that ethical beliefs were associated with ethical behaviour in the work place (Olayiwola, 2016; Román \& Luis Munuera, 2005). These findings also support study of Barrainkua and Espinosa-Pike, (2018) which demonstrated that moral belief influence ethical judgment in the work place. Findings also reveal that work experience had inverse significant relationship with fraud intent behaviour. This was consistent with the work of Barrainkua and Espinosa-Pike (2018) who found that experienced employees are less likely to commit fraud. In addition, results from various works on professional ethics, older and more experienced financial professionals are found to express stricter moral judgment in professional situations than younger and fairly experienced employees (Román \& Luis Munuera, 2005; Barrainkua \& Espinosa-Pike, 2018; Said, Alam, Ramli, \& Rafidi, 2017).

The first hypothesis which proposed that bank employees' personality traits of conscientiousness, agreeableness and openness to experience would jointly and singly predict fraudulent behaviour was tested with appropriate statistics and the result revealed that it was only conscientiousness significantly predicted bank employees' fraudulent behaviour. This in agreement with O'Brien (2015) review that three of the five personality dimensions, Neuroticism, Agreeableness, and Conscientiousness were consistently demonstrated as significant predictor of workplace deviant behaviour (Berry et al., 2007; Mount et al, 2006). Of all the three conscientiousness remain the most consistent (Berry et al., 2007; O'Brien, 2015; Mount et al, 2006). This finding is consistent with that of Penney et al. (2011) who found that employees who are high on conscientiousness are less likely to be involved in acts of counter productive work behavior. In the same vein the findings support the study of Van Staden (2018) who confirmed that negative relationships exist between conscientiousness and counterproductive work behaviour, and a positive relationship between conscientiousness and integrity.

For hypothesis two, result confirmed that there were significant influences of ethical ideologies/statuses on fraudulent behaviours, as absolutist reported lesser fraudulent behavior than that exceptionist ethical status. This is consistent with some empirical evidences that most financial institution employees have ethical ideological orientations were more ethical in their behaviour in the work place (Olayiwola, 2016); Barrainkua \& Espinosa-Pike, 2018; Román \& Luis Munuera, 2005). The finding agrees with Siu, Hui \& Lee, (2001) who found that people who are Absolutists in ethical orientation tend to refuse unethical consumer behaviour compared to those with subjectivist and exceptionist ethical orientation which condone such acts. This finding is similar to that of Dubinsky, Nataraajan, and Huang (2004) who found that sales representatives with absolutist ethical position were less likely to be involved in unethical sale behaviour compared to the subjectivists.

\subsection{Implication for practice}

This research expands our interpretation of the influence of motive on fraud intention looking at personality and ethical belief. The research gives insight into the human traits associated with fraud tendency to add to the current literature. Understanding the fundamental causes that affect the intentions of deception can help professionals to establish reliable methods of identifying potential employee likely 
to commit fraud. In specific, personality profile should be taken into account, towards preventing situations and individuals from committing misconduct by improving the efficacy of screening and ethical reorientation of workers. This knowledge may be used to establish standards of ethical conformity and training programs encouraging workplace practices that deter employees from fraud. It is also important to note that individual characteristics and pre-employment training have become a more common procedure (Brink et al., 2015; Mantell 2011). Prevention of deception in the administration of human capital is important because it is beneficial for organisations. Studies like this offer valuable knowledge for professionals who use research information on the associations between particular personality attributes and attractive employee characteristics in hiring decisions and job placements.

\section{Conclusions}

In this study, personality and individual ethical beliefs have been demonstrated to influence employees' fraudulent intent behavior. It was concluded that fraud behaviour is a product of both personality and ecological or situational factors (Duffield \& Grabosky, 2001). This understanding justifies the ramifications that, individual vary in their affinity to commit fraud but it is best resisted by those with sound ethical reasoning and conscientious personality. The way to comprehension and inevitably controlling fraud is to consider both the individual dispositional factors and the moral environment where employees' works rather than situating fraud control in only work processes and accounting procedures. It is advised that integrity assessments should be integrated into the battery of test instruments used for selection of employees into the banking organizations. This is an effective of way of controlling for people with dubious character from getting into the organization. However, integrity assessment may largely not be as effective as criminal arraignment and extreme punishment for perpetrators which will help in sending message to the potential fraudster towards deterring their intended fraudulent behaviour. This study is limited due to its correlational method as well as the population limited to inner city business clusters in the Ibadan metropolis; thus, wider generalization to all employees in Nigeria is limited. Social response bias may be another source of limitation due to the sensitive nature of fraud in the Nigerian banking system. Future studies should include larger sample size and criminal justice population (incarcerated fraudsters) in their investigations about fraud. Future studies should also consider role of organizational culture, job motivation and supervisory pressure in fraud behaviour research.

\section{References}

Adebayo S.O. \& Nwabuoku U.C. (2008) Conscientiousness and perceived organizational support as predictors of employees' absenteeism. Pakistan Journal of Social Sciences, 5, 363-367.

Abiola, I. \& Adedokun, T. O. (2018) Accounting Ethics and Professionalism on Fraud Management: Nigerian Experience. Sumerianz Journal of Economics and Finance, 1(2), 49-59.

Akinfala, F. O. (2005). Fraudulent behaviours among bank employees in Nigeria: a psychological analysis (Unpublished doctoral dissertation). Department of Psychology, University of Lagos, Akoka, Nigeria.

Akinyomi O. J. (2012) Examination of fraud in the Nigerian banking sector and its prevention. Asian Journal of Management Research, 3(1), 184 - 192. 
Alarape, A.I. (2004) Situational and personality predictors of fraudulent intent of bank employees in western Nigeria. A Ph.D. thesis submitted to Department of Psychology, University of Ibadan (Unpublished).

Ayuba, B., \& Aliyu, I. A. (2018). Unethical Business Practices in Nigeria: Causes, Consequences and Control. International Review of Business Research Papers, 14(2),1-231.

Balogun, S. K., Selemogwe, M., \& Akinfala, F. (2013). Fraud and Extravagant Life Styles Among Bank Employees: Case of Convicted Bank Workers in Nigeria. Psychological Thought, 6(2), 252-263. https://doi.org/10.5964/psyct.v6i2.68.

Barrainkua, I., \& Espinosa-Pike, M. (2018). The influence of auditors' professionalism on ethical judgement: Differences among practitioners and postgraduate students. Revista de Contabilidad, 21(2), 176-187. https://doi.org/10.1016/j.rcsar.2017.07.001

Baskaran, S., Yang, L. R., Yi, L. X., \& Mahadi, N. (2018). Ethically Challenged Strategic Management: Conceptualizing Personality, Love for Money and Unmet Goals. International Journal of Academic Research in Business and Social Sciences, 8(4), 293-311.

Berry, C. M., Ones, D. S., \& Sackett, P. R. (2007). Interpersonal deviance, organizational deviance, and their common correlates: a review and meta-analysis. Journal of Applied Psychology, 92(2), 410.

Bezuidenhoud, L. (2014) Constructing An organisational Climate Model to Predict Potential Risk of Management Fraud. A Thesis submitted in to the University of South Africa.

Boyle, B.A. (2000), "The impact of customer characteristics and moral philosophies on ethical judgments of salespeople". Journal of Business Ethics, 23(3), 249-67.

Burnett, E. A., (2017)."Bad Behavior with Good Intentions: The Role of Organizational Climate in Unethical Pro-Organizational Behavior" All Theses. 2608.https://tigerprints.clemson.edu/all_theses/2608.

Buyl, T., Boone, C., \& Wade, J. B. (2017). CEO Narcissism, Risk-Taking, and Resilience. Journal of Management, 014920631769952. https://doi.org/10.1177/0149206317699521.

Brink, A.G., Cereola, S.J. \& Menk, K. B.ryan (2015). The Effects of Personality Traits, Ethical Position, and the Materiality of Fraudulent Reporting on Entry-level Employee Whistleblowing Decisions. Journal of Forensic \& Investigative Accounting, 7(1), 180-211

Camps, J., Stouten, J., \& Euwema, M. (2016). The Relation Between Supervisors' Big Five Personality Traits and Employees' Experiences of Abusive Supervision. Frontiers in psychology, 7, 112. https://doi.org/10.3389/fpsyg.2016.00112.

Chirumbolo, A. (2017). Personality and Work Behavior in Zeigler-Hill, V. \& Shackelford, T.K. (eds.), Encyclopaedia of Personality and Individual Differences. https://doi.org/10.1007/978-3-31928099-8_793-1

Cohen, L. E., \& Felson, M. (1979). Social Change and Crime Rate Trends A Routine Activity Approach. American Sociological Review, 44, 588-608.

Crane, A., \& Glozer, S. (2016). Researching Corporate Social Responsibility Communication: Themes, Opportunities and Challenges. Journal of Management Studies, 53(7), 1223-1252. https://doi.org/10.1111/joms.12196. 
Dubinsky, A. J., Nataraajan, R., \& Huang, W.-Y. (2004). The Influence of Moral Philosophy on Retail Salespeople's Ethical Perceptions. Journal of Consumer Affairs, 38(2), 297-319. https://doi.org/10.1111/j.1745-6606.2004.tb00870.

Duffield, G., \& Grabosky, P. (2001). The Psychology of Fraud. In Trends and Issues in Crime and Criminal Justice, Australian Institute of Criminology (199). http//www.aic.gov.au.

Eysenck, H. J. (1964). Principles and Methods of Personality Description, Classification and Diagnosis. British Journal of Psychology, 55(3), 284-294. https://doi.org/10.1111/j.20448295.1964.tb00912.x

Forsyth, D.R, (1980). A Taxonomy of Ethical Ideologies. Journal of Personality and Social Psychology, $39,175-184$.

Forsyth, D.R. (1992) Judging the Morality of Business Practices: The Influence of Personal Moral Philosophies. Journal of Business Ethics, 11, 461-470.

Goldberg, L. R. (1999). A broad-bandwidth, public-domain, personality inventory measuring the lowerlevel facets of several five-factor models in Mervielde, I. Deary, I. J. DeFruyt, F, \& Ostendorf, F. (Eds.), Personality psychology in Europe (Vol. 7, pp. 7-28). Tilburg, The Netherlands: Tilburg University Press.

Gottschalk, P. (2016). Limits to private internal investigations of white-collar crime suspicions: The case of Scandinavian bank Nordea in tax havens. Cogent Social Sciences, 2(1). https://doi.org/10.1080/23311886.2016.1254839

Gurbuz, E., \& Eris, E. (2015). The Effect of Personal Idealism, Relativism, and Machiavellianism on Voting Tendency: A Turkish Study. Journal of Political Marketing, 15(1), 45-69. https://doi.org/10.1080/15377857.2014.959683

Hampson, S. E. (2012). Personality Processes: Mechanisms by which Personality Traits "Get Outside the Skin." Annual Review of Psychology, 63, 315-339. http://doi.org/10.1146/annurev-psych120710-100419.

Henle, C. A., \& Gross, M. A. (2013). An examination of the relationship between workplace deviance and employee personality. Deviant and Criminal Behavior in the Workplace, 50-70.

Iyiola, A.R. (2011) Gender and Racial Differentials in the Nigerian Banking Industry. International Journal of Business and Management, 6(9), 228 - 230

Jones, H. S., Towse, J. N., Race, N., \& Harrison, T. (2019). Email fraud: The search for psychological $\begin{array}{lllll}\text { predictors of } & \text { susceptibility. }\end{array}$ https://doi.org/10.1371/journal.pone.0209684.

Kassem, R.\& Higson, A.W. (2012). The new fraud triangle model. Journal of Emerging Trends in Economics and Management Sciences, 3(3), 191-195

Khalid, K., Eldakak, S.E., \& Loke, S. (2017). A Structural Approach to Ethical Reasoning: The Integration of Moral Philosophy. Academy of Strategic Management Journal, 16(1), 81-113.

Kretzschmar, L. \& Tuckey, E.C. (2017). The role of relationship in moral formation: An analysis of three tertiary theological education institutions in South Africa. In die Skriflig, 51(1), 1-8. https://dx.doi.org/10.4102/ids.v51i1.2214. 
Lavery, B., Siegel, A. W., Cousins, J. H., \& Rubovits, D. S. (1993). Adolescent risk-taking: An analysis of problem behaviors in problem children. Journal of Experimental Child Psychology, 55(2), 277 294.

Lefkowitz, J. (2017) Ethics and values in industrial-organizational psychology. New York: Routledge.

Lopes, C. A. (2010). Consumer morality in times of economic hardship: evidence from the European Social Survey. International Journal of Consumer Studies, 34(2), 112-120. https://doi.org/10.1111/j.1470-6431.2009.00845.x

Manurung, D., Suhartadi, A. R., \& Saefudin, N. (2015). The Influence of Organizational Commitment on Employee Fraud with Effectiveness of Internal Control and Organizational Justice as a Moderating Variable. Procedia - Social and Behavioral Sciences, 211, 1064-1072. https://doi.org/10.1016/j.sbspro.2015.11.142

Mohd Ghazali, N. A., \& Ismail, S. (2013). The influence of personal attributes and organizational ethics position on accountants' judgments: Malaysian scenario. Social Responsibility Journal, 9(2), 281297. https://doi.org/10.1108/srj-08-2011-0072

Monga, M. (2005). Value orientations: a case study of north Indian manufacturing managers. Journal of Management Development, 24(7), 632-644. https://doi.org/10.1108/02621710510608768.

Morales, J., Gendron, Y., \& Guénin-Paracini, H. (2014). The construction of the risky individual and vigilant organization: A genealogy of the fraud triangle. Accounting, Organizations and Society, 39(3), 170-194. https://doi.org/10.1016/j.aos.2014.01.006.

Moses, T. (2019). Corruption, Financial Statement Fraud, and Business Failure in Nigeria. South Asian Journal of Social Studies and Economics, 2(4), 1-10. https://doi.org/10.9734/sajsse/2018/v2i429627.

Murphy, P. R., \& Dacin, M. T. (2011). Psychological Pathways to Fraud: Understanding and Preventing Fraud in Organizations. Journal of Business Ethics, 101(4), 601-618. https://doi.org/10.1007/s10551-011-0741-0.

Nigeria Deposit Insurance Corporation (NDIC) (2018) Annual Report. https://ndic.gov.ng/wpcontent/uploads/2020/08/Year-2018-Annual-Report.pdf

Nwankwo, G. O. (2005). Bank Management Principles and practices, Lagos. Malthouse Press Ltd.

O'Brien, C. (2015) Behavioral Characteristics of White-Collar Crime and the Pre-Employment Hiring Process. Dissertation, Georgia State University, 2015. https://scholarworks.gsu.edu/bus_admin_diss/58.

Olayiwola, R.O. (2016) Ethical Climate's Relationship to Job Satisfaction, Organisational Commitment and Turnover Intention among Employees. MSc. Thesis Submitted to the Institute of Graduate Studies and Research. Eastern Mediterranean University, Gazimağusa, North Cyprus.

Othman, R., Omar, N., Azam, A., Ibrahim, S., Farouq, W. A., Rustam, N., \& Aris, N. A. (2014). Influence of Job Satisfaction and Codes of Ethics on Integrity among Police Officers. Procedia Social and Behavioral Sciences, 145, 266-276. https://doi.org/10.1016/j.sbspro.2014.06.034.

Owolabi, A. B., \& Babalola, S. S. (2011). Effect of perceived inequality and perceived job insecurity on fraudulent intent of bank employees in Nigeria. Europe's Journal of Psychology, 7(1), 199-111.

Owolabi, S. A. (2010). Fraud and fraudulent practices in Nigeria banking industry. African Research Review, 4(3), 3240-256. https://doi.org/10.4314/afrrev.v4i3.60263 
Penney, L.M., Hunter, E.M., \& Perry, S.J. (2011). Personality and counterproductive work behaviour: Using conservation of resources theory to narrow the profile of deviant employees. Journal of Occupational and Organizational Psychology, 84, 58-77.

Poór, J., Abdulkerim, Y., Ahmet B., \& Kollár P. (2018). Comparative Business Ethics - Idealism and Relativism in Light of Empirical Researches in Eight CEE Countries, Finland, and Turkey. International Journal of Management Science and Business Administration, 4(5), 23-33.

Román, S., \& Luis Munuera, J. (2005). Determinants and consequences of ethical behaviour: an empirical study of salespeople. European Journal of Marketing, 39(5/6), 473-495. https://doi.org/10.1108/03090560510590674.

Said, J., Alam, M.M., Ramli, M., \& Rafidi, M. (2017). Integrating ethical values into fraud triangle theory in assessing employee fraud: Evidence from the Malaysian banking industry. Journal of International Studies, 10(2), 170-184. https://doi.org/10.14254/2071-8330.2017/10-2/13

Savur, S., Provis, C., \& Harris, H. (2018). Ethical decision-making in Australian SMEs: a field study. Small Enterprise Research, 25(2), 114-136. https://doi.org/10.1080/13215906.2018.1480414.

Schlenker, B. R., \& Forsyth, D. R. (1977). On the ethics of psychological research. Journal of Experimental Social Psychology, 13(4), 369-396.

Schlenker, B., \& Forsyth, D. (1977). On the Ethics of Psychological Research. Journal of Experimental Social Psychology, 13, 369-396.

Singh, J. B., Wood, G., Callaghan, M., Svensson, G., \& Andersson, S. (2018). Operationalizing business ethics in organizations. European Business Review, 30(4), 494-510. https://doi.org/10.1108/ebr05-2017-0101.

Sinha, K. (2004). How Much Personality Influence Job Performance. www.Personality research.Org/papers/neubert.html.

Siu, N., Hui, A., \& Lee, B. (2001). An empirical investigation of the ethical beliefs of consumers in China.Business Research Centre Papers on China, Hong Kong Baptist University, pp. 1-30. URL:http://net2.hkbu.edu.hk/ brc/CP200103.pdf.

Soleye, O. (1989). Work and Government Work. Faculty of the Social Sciences Lecture delivered at the University of Ibadan.

Tawiah, S.R. (2017) Combating Fraud - The Role of Forensic Auditing in Financial Institutions, A Case Study of Barclays Bank Ghana Limited, Tamale Main Branch, in the Northern region of Ghana. A thesis submitted to the University of Ghana, Legion. Retrieved www.udsspace.uds.edu.gh

Teachout, Z. (2018). The Problem of Monopolies \& Corporate Public Corruption. Dadalus, 147(3), 112.

Thomson, M., Kentikelenis, A., \& Stubbs, T. (2017). Structural adjustment programmes adversely affect vulnerable populations: a systematic-narrative review of their effect on child and maternal health. Public Health Reviews, 38(1). https://doi.org/10.1186/s40985-017-0059-2.

Trevino, L. K. \& Nelson, K. A. (2007). Managing Business Ethics, 4th ed. Hoboken, NJ Wiley.

Turner, M. J. (2014). An Investigation of Big Five Personality and Propensity to Commit White-Collar Crime. Advances in Accounting Behavioral Research, 57-94. https://doi.org/10.1108/s147514882014000001700. 
Uchenna, C. \& Agbo, J.C. (2013). Impact of fraud and fraudulent practices on the performance of banks in Nigeria. British Journal of Arts and Social Sciences 15(1),12-28.

Udeh, S. N., \& Ugwu, J. I. (2018). Fraud in Nigerian Banking Sector. International Journal of Academic Research in Business and Social Sciences, 8(5), 589-607.

Van Staden, O.S. (2018) Relationship between personality, integrity and counterproductive work behaviour: a Namibian study. Master of Commerce (Industrial Psychology) Thesis submitted to the Faculty of Economic and Management Sciences, Stellenbosch University.

Weber, J., Kurke, L. B., \& Pentico, D. W. (2003). Why do Employees Steal?. Business \& Society, 42(3), 359-380. https://doi.org/10.1177/0007650303257301.

Wicaksono, A.P. \& Urumsah. D. (2016) Factors Influencing Employees to Commit Fraud in Workplace Empirical Study in Indonesian Hospitals. Asia Pacific Fraud Journal, 1(1),1-18. https://doi.org/ 10.21532/apfj.001.16.01.01.01.

Wolfe, D., \& Hermanson, D. R. (2004). The fraud diamond: Considering four elements of fraud. The CPA Journal,74(12), 38-42.

Zulaikha, G. I., \& Hadiprajitno, P. T. (2016). Factors affecting the government procurement fraud: The independent auditor's point of view. Evidence from Indonesia. Corporate Board: role, duties and composition, 12(3), 61-68. http://doi.org/10.22495/cbv12i3art7

World Medical Association. (2001). World medical association declaration of Helsinki ethical principles for medical research involving human subjects. Bulletin of the World Health Organization, 79(4), 373-374. Retrieved from https://www.who.int/bulletin/archives/79\%284\%29373.pdf. 
Sifat Kepribadian dan Keyakinan Etis sebagai Faktor yang Mempengaruhi Perilaku Niat

\author{
Penipuan di antara Karyawan Bank di Ibadan, Nigeria
}

\begin{abstract}
Abstrak
Penipuan adalah masalah yang terus berkembang untuk lembaga keuangan di Nigeria, dengan penjahat menggunakan berbagai metode. Sayangnya, sebagian besar aktivitas penipuan ini melibatkan para karyawan. Studi sebelumnya berfokus pada anteseden kontekstual dan organisasi untuk memotivasi keterlibatan dalam praktik curang dan kurang pada faktor disposisional karyawan. Penelitian ini menguji peran ciri-ciri kepribadian dan keyakinan etis terhadap perilaku curang di kalangan pegawai bank. Penelitian ini merupakan studi potong lintang. Tiga ratus lima puluh tiga (353) karyawan kader manajemen tingkat menengah hingga junior dipilih melalui teknik stratified sampling dari organisasi perbankan yang beroperasi di kota metropolitan Ibadan. Responden menanggapi kuesioner laporan diri yang mengukur niat perilaku curang dan bendera merah; ciri-ciri kepribadian dan kuesioner posisi etis. Dua hipotesis diuji dengan menggunakan regresi berganda, analisis korelasi Pearson dan ANOVA pada $\mathrm{p} \leq 0.05$. Hasil penelitian menunjukkan bahwa sifat kepribadian conscientiousness adalah satu-satunya prediktor perilaku niat penipuan di antara variabel kepribadian. Karyawan dengan prinsip etika absolut melaporkan perilaku niat penipuan yang lebih rendah daripada mereka yang memiliki filosofi etika subjektivis. Studi tersebut menyimpulkan bahwa ciri-ciri kepribadian dan keyakinan etis adalah motivator yang kuat untuk perilaku penipuan. Oleh karena itu, ahli penipuan dan SDM disarankan untuk menggunakan profil psikologis dalam investigasi penipuan dan pemilihan karyawan.
\end{abstract}

Kata kunci: penipuan bank, ciri-ciri kepribadian, sifat teliti, keyakinan etis, keyakinan etis absolut, karyawan bank 